\title{
Pengelasan Litostratigrafi Baru untuk Formasi Singa di Langkawi, Kedah, Malaysia
}

(New Classification for Lithostratigraphy of the Singa Formation in Langkawi, Kedah, Malaysia)

\section{Mohamad Hanif Kamal Roslan, Che AzIZ Ali \& Kamal Roslan MoHamed*}

\begin{abstract}
ABSTRAK
Semakan semula litostratigrafi Formasi Singa dilakukan berdasarkan data-data baru yang diperoleh melalui kajian terbaru. Secara umumnya, Formasi Singa dominan dengan batu lumpur hitam yang berselang lapis dengan batu pasir nipis hingga sederhana tebal serta sedikit lapisan konglomerat. Kajian melibatkan analisis terhadap beberapa log sedimen yang telah direkodkan di lapangan. Kesemua log sedimen tersebut telah dikorelasikan untuk mendapatkan satu log komposit yang mewakili keseluruhan Formasi Singa. Berdasarkan kajian terperinci korelasi litologi yang dilakukan, cadangan litostratigrafi baru Formasi Singa mengandungi empat ahli iaitu Ahli Kentut, Ahli Ular, Ahli Selang dan Ahli Lembung. Ahli Kentut merupakan ahli yang paling tua diikuti dengan Ahli Ular, Ahli Selang dan Ahli Lembung. Ahli Ular di dalam Formasi Singa dianggap sebagai satu unit kekanta antara Ahli Kentut dengan Ahli Selang. Beberapa siri perubahan paras laut ditafsirkan sepanjang pengendapan batuan Formasi Singa dipercayai akibat daripada proses pencairan glasier yang menyebabkan paras laut meningkat dan pengendapan berterusan yang menyebabkan lembangan menjadi cetek dan paras laut menjadi rendah.
\end{abstract}

Kata kunci: Formasi Singa; geologi Langkawi; stratigrafi

ABSTRACT

A review of lithostratigraphy of the Singa Formation is based on new data, which was obtained through the latest study conducted. Generally, Sing a Formation is dominant with black mud stones, which are interbedded with medium to thick sandstone and some conglomerate layers. The study involved analysis of some sedimentary logs that were recorded in the field. All sedimentary logs were then correlated to get a composite log that represents the entire sequence of the Sing a Formation. Based on detail study of lithologic correlation, a new lithostratigraphy of the Singa Formation which consists of four members, namely Kentut Member, Ular Member, Selang Member and Lembung Member is proposed. Kentut Member is the oldest member while Lembung Member is the youngest member. Ular Member was considered as the lenses between Kentut and Selang Member. A series of sea level changes were interpreted throughout the deposition of Sing a Formation that are believe due to the melting of glacier that cause the sea level to rise and continuous deposition of sediment that cause the basin to become shallow and lowering the lea level.

Keywords: Geology of Langkawi; Singa Formation; stratigraphy

\section{PENGENALAN}

Jones (1966) menamakan Formasi Singa untuk batuan sedimen klastik yang berusia Karbon hingga Perm di sekitar Kepulauan Langkawi. Formasi ini didominasi dengan jujukan batuan argilit seperti batu lumpur, syal dan batu lodak, serta terdapat juga lapisan batu pasir dan sedikit konglomerat. Hubungan stratigrafi antara Formasi Singa dengan formasi lain di Langkawi ditunjukkan dalam Rajah 1. Formasi Singa banyak tertumpu di bahagian barat daya Langkawi terutamanya di pulau-pulau kecil bermula daripada Pulau Rebak Besar hinggalah ke Pulau Singa Besar di selatan. Ahmad Jantan (1973) telah membahagikan Formasi ini kepada empat ahli iaitu Ahli Rebak, Ahli Kentut, Ahli Ular dan Ahli Selang. Kertas kerja ini bertujuan untuk membuat semakan semula pembahagian unit litostratigrafi bagi keseluruhan Formasi
Singa berdasarkan data lapangan dan analisis fasies baru yang diperoleh melalui kajian yang dijalankan.

\section{STATUS AHLI REBAK}

Ahli Rebak yang diperkenalkan oleh Ahmad (1973) sebagai salah satu unit litostratigrafi dalam Formasi Singa tersingkap di Pulau Rebak Besar, Pulau Rebak Kechil dan Pulau Langgun. Beberapa pengkaji lain mempunyai tafsiran yang berbeza tentang jujukan batuan yang terdapat di pulau ini. Ibrahim Abdullah (1997), Jones (1981, 1966) dan Koopmans (1965), menyatakan batuan di Pulau Rebak Besar adalah sebahagian daripada Formasi Machinchang, Gobbett (1972) mencadangkan unit batuan baru iaitu Lapisan Rebanggun, manakala Khoo (1984) mencadangkan Formasi Setul. Mat Niza et al. (2014) 
telah mengeluarkan Ahli Rebak daripada Formasi Singa dan telah memperkenalkan unit baru Formasi Rebak untuk jujukan batuan di Pulau Rebak Besar, Pulau Rebak Kechil dan Pulau Langgun ini. Kajian fosil dan penelitian semula usia Formasi Singa oleh Mohamad Hanif et al. (2017) mendapati terdapat perbezaan usia yang besar antara Ahli Rebak dengan ahli-ahli lain dalam Formasi Singa (Hamada 1969, 1968; Kobayashi \& Hamada 1973; Leonova et al. 1999; Mohd Shafeea 2003, 1997a, 1997b, 1996; Sarkar 1972; Shi et al. 1997; Yancey 1972) dan menyokong cadangan Mat Niza et al. (2014) supaya Ahli Rebak dikeluarkan daripada Formasi Singa untuk menjadi satu formasi lain yang tersendiri. Dalam kertas ini, Formasi Singa yang diperincikan untuk pengelasan litostratigrafi baru tidak mengambil kira Ahli Rebak.

\section{TABURAN FORMASI SINGA}

Secara umumnya di Langkawi, Formasi Singa terdiri daripada batuan sedimen argilit, berbanding dengan Formasi Machinchang yang kaya dengan sedimen arenit dan Formasi Setul serta Formasi Chuping yang keduaduanya dominan dengan batu kapur. Formasi Singa dominan dengan batu lumpur hitam yang berselang lapis dengan batu pasir nipis hingga sederhana tebal serta sedikit lapisan konglomerat dalam bentuk palong. Di tempat-tempat tertentu, dalam batu lumpur hitam ini pula boleh ditemui pebel berbagai jenis, saiz dan bentuk yang dikaitkan dengan proses endapan glasier di kawasan sejuk.

Jujukan batuan Formasi Singa tertabur di pulau-pulau kecil di bahagian baratdaya kepulauan Langkawi serta juga di pulau besar Langkawi seperti ditunjukkan dalam Rajah 1. Dalam rajah ini, jujukan batuan di Pulau Rebak Besar, Pulau Rebak Kecil dan Pulau Langgun telah dikeluarkan daripada Formasi Singa.

\section{KORELASI LOG SEDIMEN}

Kawasan kajian telah dibahagikan kepada lapan zon bagi memudahkan korelasi log dilakukan (Rajah 1). Jujukan batuan sedimen di setiap zon dikorelasikan terlebih dahulu sebelum korelasi keseluruhan Formasi Singa dibuat. Secara ringkas Zon A terdiri daripada Pulau Beras Basah, Pulau Intan Kecil dan Pulau Intan Besar. Zon B terdiri daripada bahagian utara Pulau Singa Besar dan Pulau Singa Kecil. Zon C pula terdiri daripada bahagian selatan Pulau Singa Besar.Zon D termasuklah Pulau Tepor dan bahagian pesisir dari Tanjung Mali hingga ke Tanjung Sawa.Zon E meliputi kawasan pesisir dari Teluk Baru hingga ke Tanjung Chengai, Pulau Ular, Pulau Selang dan Pulau Lalang. Zon F meliputi singkapan di sepanjang Jalan Bukit Malut dan beberapa singkapan di Jalan Padang Mat Sirat. Zon G pula terdiri daripada singkapan di Batu Asah, Kelibang, Taman Helang Perdana dan sekitar Kuah. Manakala Zon H pula terdiri daripada singkapan di Kuari Sungai Itau dan Kilim. Log sedimen bagi setiap zon dikorelasikan untuk mendapatkan satu log komposit yang meliputi keseluruhan kawasan kajian. Pembahagian terperinci fasies sedimen untuk keseluruhan Formasi Singa telah dilakukan oleh Mohamad Hanif et al. (2016) dan mereka telah membahagikan Formasi Singa kepada sepuluh fasies sedimen dan empat sekutuan fasies. Untuk kajian ini,

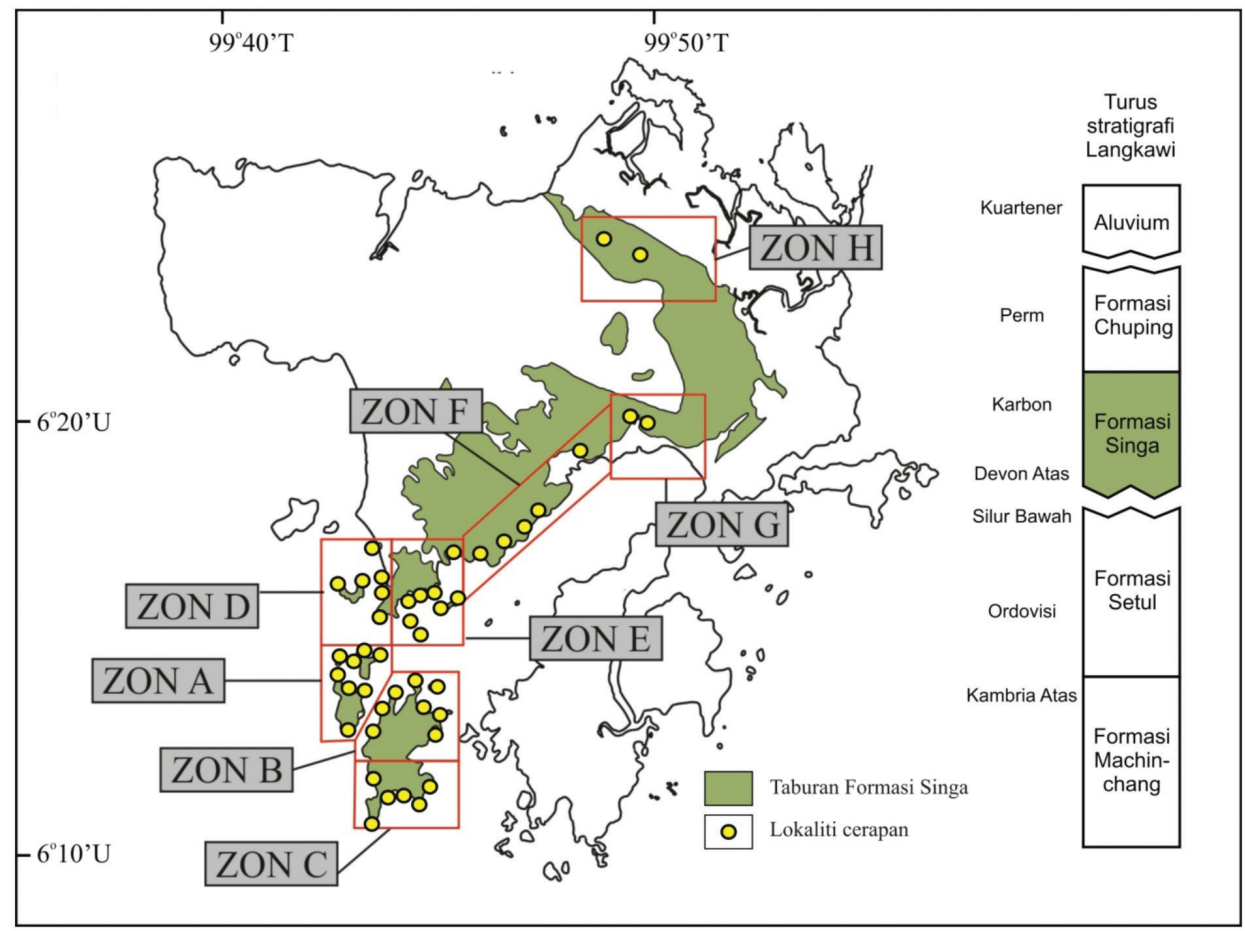

RAJAH 1. Stratigrafi Langkawi oleh Jones (1981), taburan Formasi Singa, lokaliti cerapan dan pembahagian zon korelasi log sedimen 
litologi dalam log komposit dibahagikan kepada 3 unit sahaja untuk memudahkan korelasi antara zon; iaitu unit dominan batu pasir, unit dominan batu lumpur dan unit selang lapis batu pasir, batu lodak dan batu lumpur.

Korelasi pada Zon A dibuat berdasarkan $13 \log$ sedimen yang ada di zon ini (Rajah 2) dan dikorelasi membentuk satu jujukan batuan setebal $550 \mathrm{~m}$. Zon ini dominan dengan batuan selang lapis antara batu pasir, batu lodak dengan batu lumpur. Jujukan batu lumpur tebal terdapat di bahagian bawah jujukan zon ini. Sedikit batu lumpur tebal terdapat pada bahagian tengah jujukan zon ini. Struktur fosil surih boleh dijumpai dengan banyak pada bahagian atas jujukan. Secara keseluruhan jujukan di zon ini membentuk jujukan yang mengkasar ke atas dengan lumpur dominan di bahagian bawah jujukan dan batuan berpasir berasosiasi dengan batu lumpur di bahagian atas jujukan.

Log komposit hasil korelasi batuan di Zon B pula membentuk jujukan setebal hampir 760 m (Rajah 3). Bahagian bawah jujukan batuan di zon ini terdiri daripada jujukan batuan sedimen klastik setebal 725 m, manakala selebihnya merupakan batuan sedimen karbonat Formasi Chuping. Formasi Chuping membentuk sempadan yang selaras dengan batuan sedimen klastik Formasi Singa di bawahnya. Bahagian bawah jujukan Zon B dominan dengan selang lapis batu pasir, batu lodak dengan batu lumpur, batu lumpur tebal, dan sedikit batu pasir tebal. Bahagian atas pula dominan dengan batu pasir tebal. Batu lumpur tebal dan selang lapis batu pasir, batu lodak dengan batu lumpur juga terdapat di bahagian atas jujukan. Jujukan di Zon B ini membentuk beberapa jujukan yang mengkasar ke atas.

Korelasi yang dibuat pada jujukan batuan di Zon C membentuk jujukan batuan setebal hampir $530 \mathrm{~m}$ (Rajah 3). Bahagian bawah jujukan terdiri daripada lapisan batu lumpur tebal yang tersingkap di barat Tanjung Genting. Jujukan batu lumpur tebal ini ditindih oleh jujukan selang lapis batu lumpur, batu lodak dengan batu pasir dan seterusnya jujukan batu pasir setebal 120 meter. Pada bahagian atas jujukan batuan di Zon C, perulangan jujukan batu lumpur tebal dan jujukan selang lapis batu lumpur, batu lodak dengan batu pasir boleh diperhatikan. Secara keseluruhannya, dua jujukan mengkasar ke atas boleh diperhatikan di dalam jujukan batuan di dalam Zon C.

Korelasi batuan di Zon D membentuk satu jujukan setebal lebih 900 m (Rajah 3). Jujukan batuan yang terbentuk di zon ini memperlihatkan beberapa siri perulangan antara lapisan batu lumpur tebal dengan selang lapis batu pasir, batu lodak dengan batu lumpur. Klastaklasta asing berbutir lebih kasar yang membentuk struktur batu jatuh boleh diperhatikan di beberapa bahagian di dalam jujukan batuan di zon ini. Lapisan batu pasir yang lebih tebal turut boleh diperhatikan antara jujukan batu lumpur dan jujukan selang lapis batu pasir, batu lodak dengan batu lumpur.

Korelasi batuan di Zon E pula membentuk jujukan setebal hampir $600 \mathrm{~m}$ (Rajah 3). Bahagian bawah jujukan terdiri daripada lapisan batu lumpur yang membentuk jujukan setebal lebih $200 \mathrm{~m}$. Pebel yang membentuk

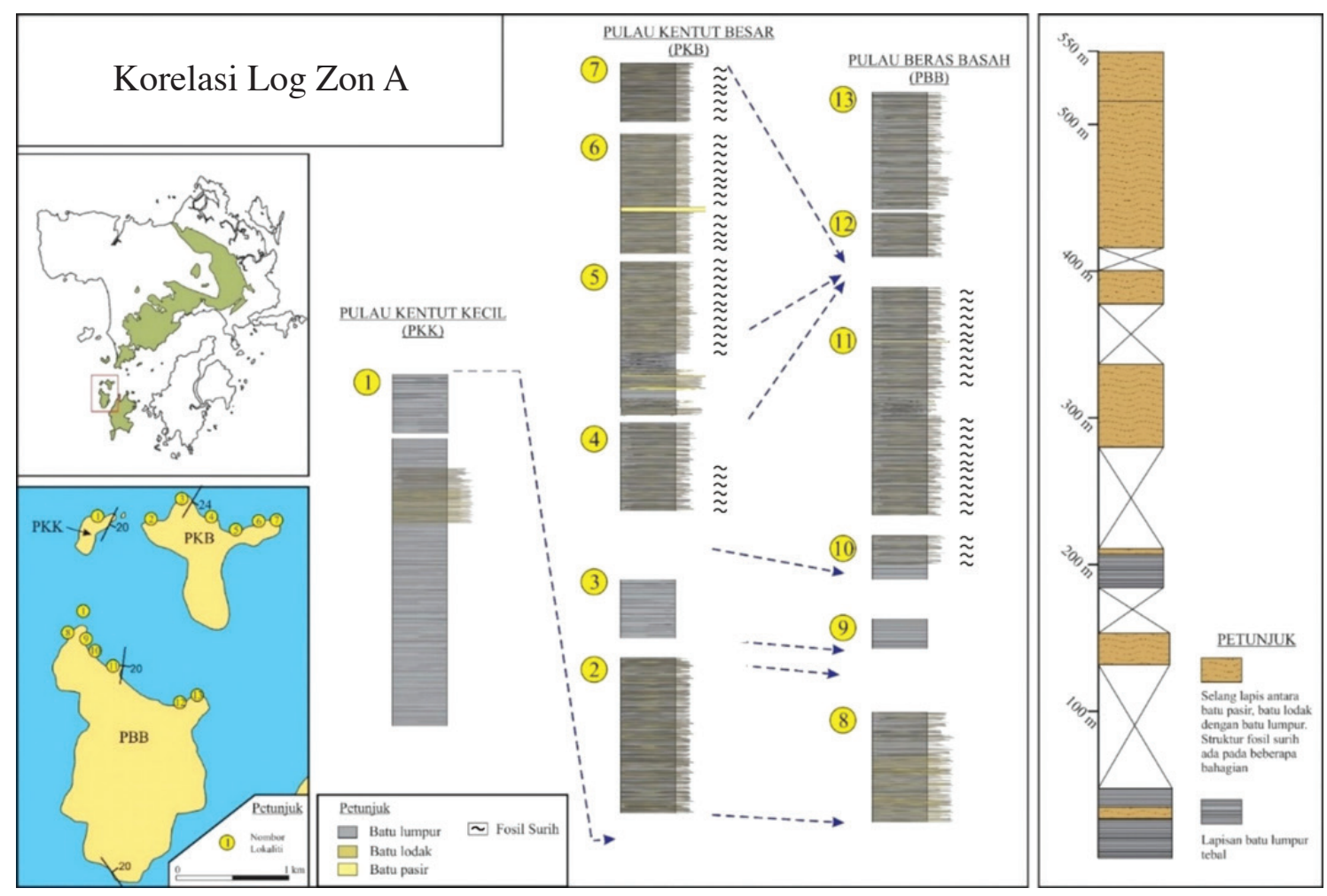

RAJAH 2. Korelasi log sedimen singkapan batuan dalam Zon A. Log sedimen di bahagian kanan ialah $\log$ komposit untuk Zon A. Perkara yang sama dilakukan untuk setiap zon 
struktur batu jatuh boleh diperhatikan di beberapa bahagian dalam jujukan ini. Jujukan lapisan batu lumpur ini ditindih oleh jujukan selang lapis batu lumpur, batu lodak dengan batu pasir setebal $30 \mathrm{~m}$ dan menghasilkan beberapa siri jujukan mengkasar ke atas. Pada bahagian atas jujukan yang kaya dengan lapisan lumpur boleh didapati himpunan fosil Bandoproductus sp. dan Spinomartinia prolifica. Struktur batu jatuh turut ditemui bersama-sama dengan lapisan berfosil di beberapa bahagian lain.

Log komposit di Zon F membentuk jujukan batuan setebal lebih $600 \mathrm{~m}$ (Rajah 3). Bahagian bawah jujukan dominan dengan batu lumpur yang berlapis dengan batu lodak serta batu pasir. Struktur batu jatuh boleh dijumpai di dalam lapisan batu lumpur di beberapa bahagian. Himpunan fosil Bandoproductus sp. boleh dijumpai di dalam lapisan batu lumpur di bahagian tengah jujukan zon ini. Bahagian atas jujukan Zon F didominasi dengan lapisan batu lumpur tebal berselang lapis dengan batu lumpur dan batu lodak pada beberapa bahagian.

Korelasi batuan di Zon G membentuk jujukan batuan setebal hampir 400 meter (Rajah 3). Bahagian bawah jujukan dominan dengan batuan berbutir halus dan berselang lapis dengan batu pasir di beberapa bahagian. Semakin ke atas, kewujudan batu pasir menjadi lebih dominan dan membentuk lapisan yang tebal. Dua himpunan fosil iaitu himpunan Spinomartinia prolifica dan Bandoproductus sp. ditemui pada singkapan di Batu Asah, Kelibang dan Taman Helang Perdana. Manakala Zon H pula melibatkan lokaliti di Kilim dan Sungai Itau dan log komposit ditunjukkan dalam Rajah 3.

Setelah kolerasi setiap zon dibuat, korelasi jujukan batuan bagi keseluruhan kawasan kajian pula dilakukan untuk mendapatkan jujukan lengkap Formasi Singa (Rajah 4). Untuk tujuan korelasi ini, maklumat fasies sedimen dan sekutuan fasies oleh Mohamad Hanif et al. (2016) turut diambil kira. Secara keseluruhannya, Formasi Singa terdiri daripada jujukan batuan sedimen klastik setebal hampir 2000 m. Bahagian bawah Formasi Singa terdiri daripada perulangan jujukan batu lumpur tebal dengan jujukan selang lapis batu lumpur, batu lodak dengan batu pasir. Ini diikuti oleh jujukan batuan yang dominan dengan batu pasir di atasnya dan akhirnya jujukan Formasi Singa ini ditindih secara selaras oleh jujukan batu kapur Formasi Chuping.

\section{UNIT LITOSTRATIGRAFI FORMASI SINGA}

Korelasi lengkap untuk Formasi Singa ditunjukkan dalam Rajah 4 dan dibahagikan kepada empat unit himpunan batuan. Unit pertama terletak pada bahagian paling bawah jujukan Formasi Singa. Unit ini didominasi oleh batu lumpur dan selang lapis batu lumpur, batu lodak dan batu pasir. Unit ini tertabur di seluruh kawasan kajian. Di atasnya terdapat unit kedua yang terdiri daripada batu pasir dominan dan selang lapis batu pasir, batu lodak dan batu lumpur. Unit kedua ini banyak ditemui di Pulau Ular dan Pulau Singa Besar. Hanya fosil surih dijumpai di dalam kedua-dua unit ini. Unit ketiga yang terletak di atas unit kedua mempunyai litologi hampir sama dengan unit pertama. Namun, banyak fosil ditemui dalam unit ini. Unit ini juga mempunyai sebaran yang luas. Unit keempat pula kaya dengan batu pasir dan merupakan unit paling atas bagi Formasi Singa. Unit keempat ditindih secara selaras oleh batu kapur Formasi Chuping.

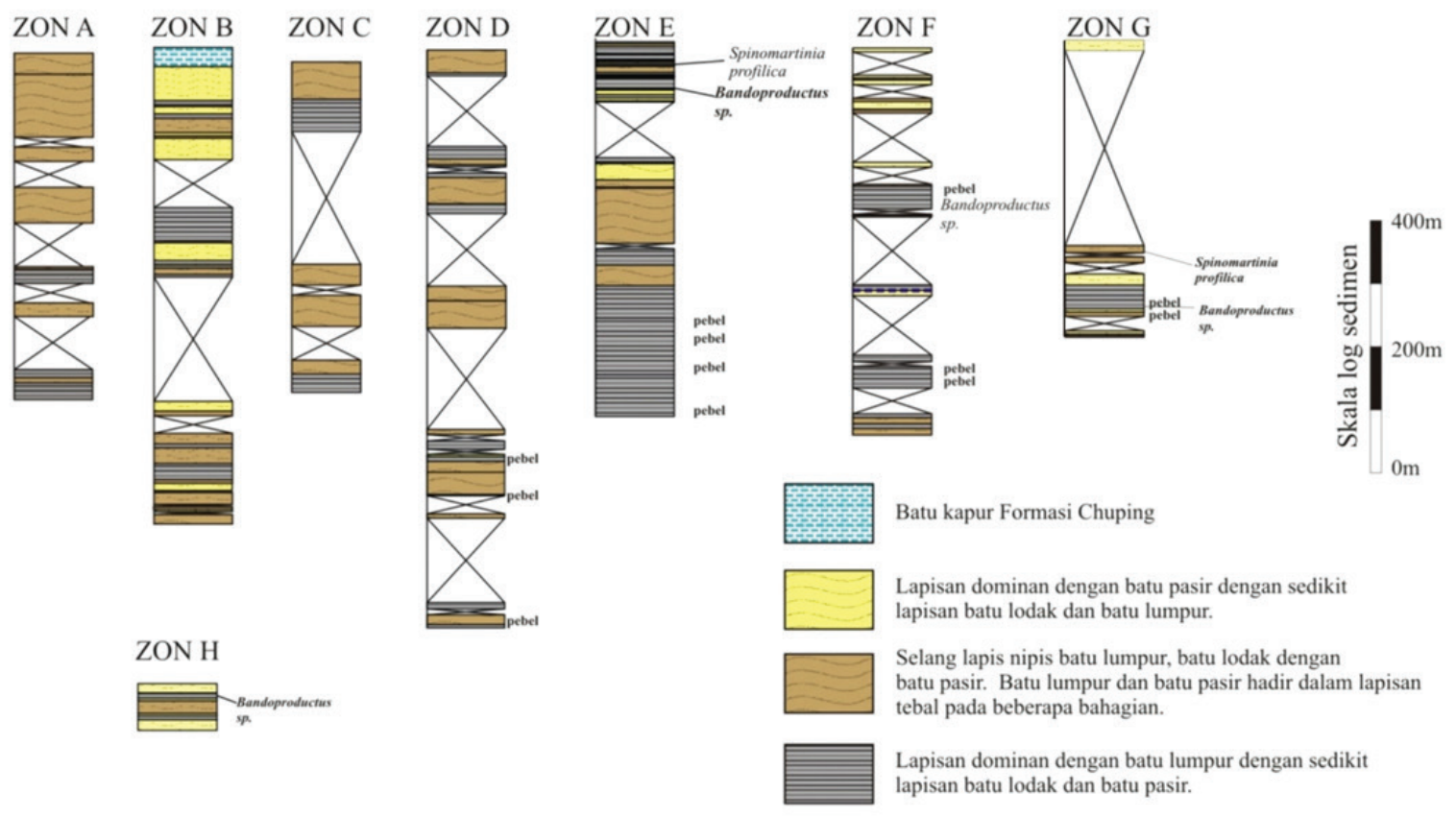

RAJAH 3. Log komposit Formasi Singa untuk setiap zon (Lokasi zon boleh dirujuk di Rajah 1) 


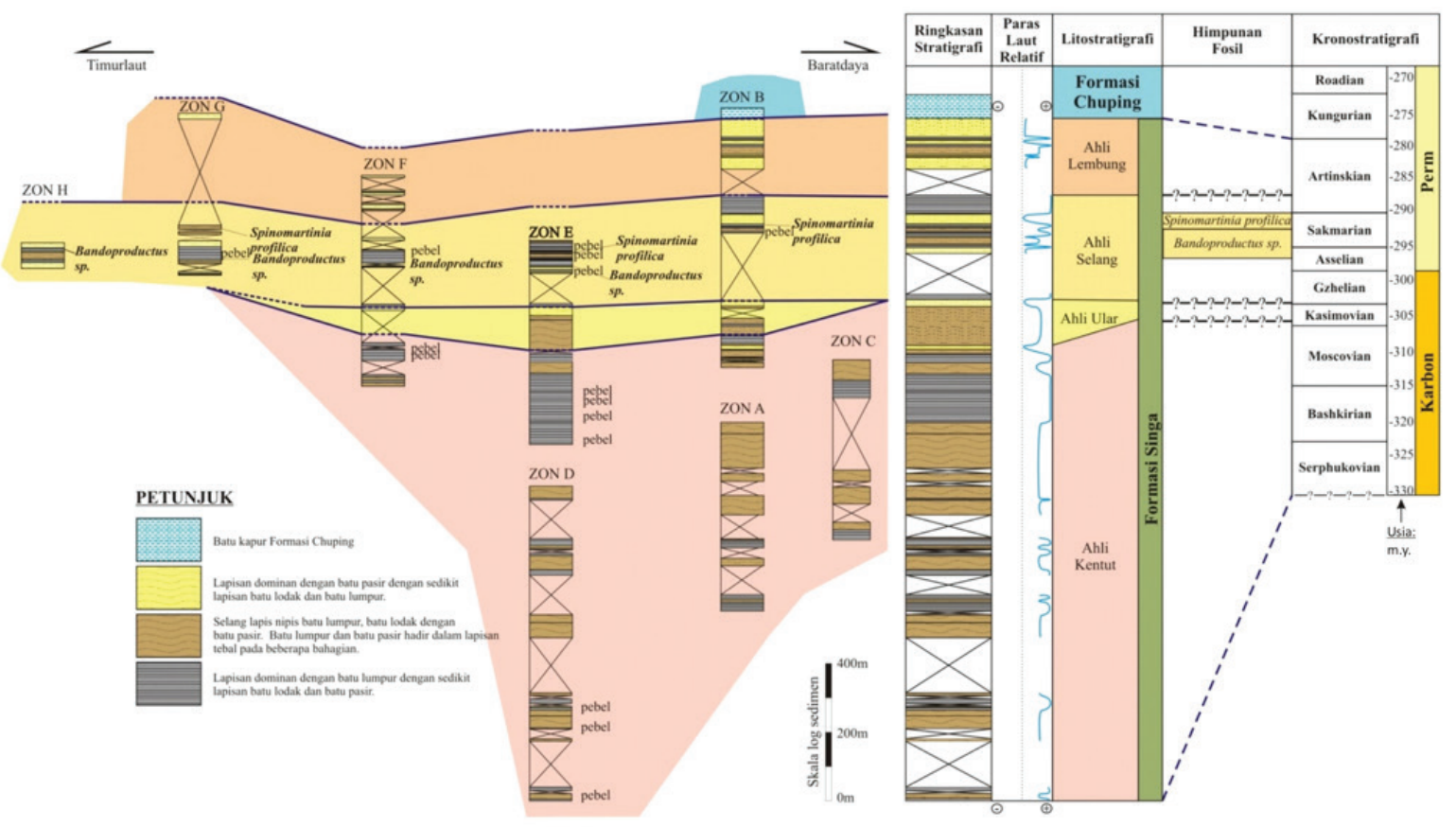

RAJAH 4. Ringkasan Stratigrafi Formasi Singa

Apabila dibandingkan ciri-ciri ahli yang ada dalam Formasi Singa oleh Ahmad Jantan (1973), dapat dibuat kesimpulan bahawa unit pertama setara dengan Ahli Kentut, unit kedua setara dengan Ahli Ular, manakala gabungan unit ketiga dan keempat adalah setara dengan Ahli Selang. Dalam kajian ini, Formasi Singa dibahagikan kepada empat ahli, iaitu Ahli Kentut (paling bawah/tua) diikuti oleh Ahli Ular, Ahli Selang dan satu ahli baru dicadangkan iaitu Ahli Lembung (paling muda).

\section{AHLI KENTUT}

Nama, taburan dan keratan tip Nama Ahli Kentut diperkenalkan oleh Ahmad (1973) sempena Pulau Kentut Besar (sekarang dikenali sebagai Pulau Intan Besar), tempat batuan unit ini boleh ditemui. Taburan Ahli Kentut di kawasan kajian merangkumi beberapa pulau-pulau kecil di baratdaya Langkawi iaitu di Pulau Tepor, Pelau Intan Besar, Pulau Intan Kecil, Pulau Beras Basah serta bahagian barat dan selatan Pulau Singa Besar. Di pulau besar (Pulau Langkawi) singkapan unit stratigrafi ini boleh diperhatikan di sepanjang kawasan pesisir dari Tanjung Mali hingga ke Tanjung Mat Sah yang turut merangkumi singkapan Bukit Batu Kulat, Tanjung Sawa, Teluk Baru, Tanjung Hantu dan Tanjung Chengai. Keratan tip untuk ahli ini ialah di sebelah barat Pulau Tepor dan bersambung ke singkapan di bahagian pesisir Pulau Langkawi daripada Tanjung Mali hingga ke Tanjung Chengai melalui kawasan Bukit Batu Kulat, Tanjung Sawa dan Tanjung hantu.

Litologi dan sempadan stratigrafi Litologi batuan unit Ahli Kentut boleh dibahagikan kepada 2 sub-unit iaitu sub-unit jujukan batu lumpur dominan dan sub-unit jujukan selang lapis batu lumpur, batu lodak dan batu pasir. Kedua-dua sub-unit menghasilkan beberapa siri jujukan mengkasar ke atas. Struktur batu jatuh yang terbentuk akibat daripada pencairan glasier boleh ditemui pada beberapa bahagian dalam unit Ahli Kentut. Batuan Ahli Kentut juga kaya dengan struktur fosil surih seperti Planolites isp., Thalassinoides isp., dan Arenicolites isp. Tiada sempadan yang jelas yang boleh diperhatikan pada bahagian paling bawah unit ini dengan Formasi Rebak dan bahagian paling bawah jujukan Ahli Kentut dan Formasi Singa dianggarkan berada di antara Pulau Tepor dan Pulau Tekun Baba.

Usia dan sekitaran pengendapan Walaupun batuan di dalam unit Ahli Kentut mempunyai banyak bukti aktiviti organisma berdasarkan kewujudan fosil surih dan struktur biokacau, usia bagi unit ini tidak boleh ditentukan dengan tepat kerana ketiadaan fosil indeks yang boleh dijadikan petunjuk usia. Oleh itu, usia bagi unit ini hanya boleh dianggarkan berdasarkan hubungan stratigrafi dengan unit batuan yang lain. Walaupun tiada sempadan yang jelas ditemui antara unit Ahli Kentut dengan Formasi Rebak yang berusia Visean (Karbon Awal), Ahli Kentut dilihat jelas menindih batuan Formasi Rebak berdasarkan keadaan jurus bagi kedua-dua unit ini yang normal. Oleh itu, bahagian bawah Ahli Kentut dan Formasi Singa adalah lebih muda daripada usia Visean dan dianggarkan berusia Serphukovian. Secara umumnya litologi bagi Ahli Kentut boleh dibahagikan kepada subunit batu lumpur tebal dan unit selang lapis batu lumpur, batu lodak dengan batu pasir. Terdapat perulangan dapat diperhatikan pada kedua-dua unit di dalam jujukan batuan Ahli Kentut dan kewujudan fosil surih laut cetek di beberapa bahagian 
jujukan. Unit batu lumpur terenap di sekitaran luar pesisir yang mempunyai keadaan yang tenang. Unit selang lapis batu lumpur, batu lodak dengan batu pasir pula terenap di sekitaran zon transisi antara muka pesisir dengan luar pesisir yang sangat dipengaruhi oleh cuaca.

\section{AHLI ULAR}

Nama, taburan dan keratan tip Nama Ahli Ular diperkenalkan oleh Ahmad (1973) sempena Pulau Ular, tempat batuan unit ini boleh ditemui. Unit Ahli Ular tersingkap di hampir keseluruhan Pulau Ular kecuali di bahagian paling selatan Pulau Ular dengan batu lumpur berpebel tersingkap (Ahli Selang). Unit Ahli Ular turut tersingkap sedikit di bahagian barat Pulau Singa Besar. Keratan tip yang sesuai ialah singkapan di hujung utara Pulau Ular hingga ke sebelah selatan Pulau Ular, tempat Ahli Selang dijumpai.

Litologi dan sempadan stratigrafi Bahagian bawah unit Ahli Ular terdiri daripada jujukan selang lapisan nipis batu lumpur, batu lodak dengan batu pasir. Dalam jujukan tersebut, fosil surih dan struktur nendatan yang jelas boleh diperhatikan di beberapa bahagian. Semakin ke atas, kehadiran batu pasir adalah menjadi dominan dan membentuk jujukan batu pasir tebal di bahagian atas unit Ahli Ular. Ahli Ular ditindih oleh Ahli Selang secara selaras dan sempadan ini boleh ditemui di bahagian selatan Pulau Ular.

Usia dan sekitaran pengendapan Usia bagi unit Ahli Ular tidak boleh dilakukan dengan tepat kerana tiada fosil indeks yang boleh digunakan untuk penentuan usia. Namun usia Ahli Ular dianggarkan berusia lebih tua daripada lapisan fosil paling muda dalam Ahli Selang yang berusia Asselian (Perm Awal). Unit Ahli Ular terdiri daripada jujukan selang lapis batu lumpur, batu lodak dengan batu pasir dengan batu pasir menjadi lebih tebal di bahagian atas jujukan. Jujukan batuan bagi unit ini ditafsirkan terendap di sekitaran laut cetek di antara zon muka transisi hingga ke zon muka pesisir. Kehadiran struktur nendatan pada beberapa bahagian dalam unit ini menunjukkan terdapat kewujudan cerun pada lembangan dengan unit ini terendap. Kewujudan alur dalam lembangan unit Ahli Selang turut diperhatikan berdasarkan kewujudan jujukan menghalus ke atas yang ditemui di bahagian baratdaya Pulau Ular.

\section{AHLI SELANG}

Nama, taburan dan keratan tip Nama Ahli Selang diperkenalkan oleh Ahmad (1973) sempena Pulau Selang, tempat batuan unit ini boleh ditemui. Unit Ahli Selang tersingkap di beberapa bahagian di sekitar Kepulauan Langkawi. Di sebelah baratdaya Kepulauan Langkawi, unit ini tersingkap di selatan Pulau Ular, Pulau Selang, Pulau Lalang, Pulau Singa Besar dan Pulau Singa Kecil. Unit ini turut tersingkap di sekitar Batu Asah, Kelibang, Taman Helang Perdana, Sungai Itau, Kilim dan Kampung Kisap. Singkapan bahagian pesisir sepanjang Tanjung
Sepai hingga ke Tanjung Pekula di Pulau Singa Besar sesuai dijadikan keratan tip untuk ahli ini.

Litologi dan sempadan stratigrafi Unit Ahli Selang terdiri daripada lapisan batu lumpur, batu lodak dan batu pasir yang berselang lapis tebal. Bahagian paling bawah unit ini mengandungi pebel kuarzit yang membentuk struktur batu jatuh. Struktur sedimen seperti pelapisan silang boleh dijumpai dalam lapisan batu pasir di beberapa bahagian terutamanya pada singkapan di Pulau Singa Kecil. Bahagian paling bawah unit ini tersingkap di bahagian paling selatan Pulau Ular di mana sempadan dengan unit Ahli Ular boleh ditemui.

Usia dan sekitaran pengendapan Unit Ahli Selang kaya dengan fosil yang membolehkan penentuan usia bagi unit ini boleh dilakukan dengan tepat. Fosil-fosil dalam unit Ahli Selang boleh dibahagikan kepada dua himpunan iaitu himpunan fosil Bandoproductus sp. dan Spinomartinia prolifica. Kedua-dua himpunan fosil ini memberikan julat usia antara Asselian hingga Sakmarian (Perm Awal). Jujukan batuan Ahli Selang ditafsirkan terendap di sekitaran yang bertenaga tinggi dengan lapisan batu pasir boleh terbentuk. Namun kewujudan lapisan batu lumpur dalam unit ini turut menunjukkan terdapat perubahan daripada sekitaran bertenaga tinggi kepada sekitaran yang tenang. Oleh itu, unit Ahli Selang ditafsirkan terendap dalam sekitaran muka pesisir dan zon transisi. Perubahan sekitaran ini ditafsirkan berlaku akibat daripada perubahan paras laut yang terjadi semasa pengendapan unit Ahli Selang.

\section{AHLI LEMBUNG}

Nama, taburan dan keratan tip Nama unit Ahli Lembung ini diambil bersempena Tanjung Lembung yang terletak di sebelah selatan Bukit Malut dengan jujukan batuan unit ini boleh ditemui. Unit Ahli Lembung tersingkap di sepanjang Jalan Bukit Malut di sebelah selatan Bukit Malut dari sekitar Tanjung Gerak hingga ke kawasan Kampung Sungai Batu. Unit ini juga tersingkap pada singkapan di sepanjang Lebuhraya Langkawi dari sekitar Kelibang hingga ke Kuah dan sepanjang Jalan Bukit Malut daripada Kuala Temoyong hingga ke kawasan Tanjung Lembung.

Litologi Ahli Lembung dominan dengan batu pasir dengan sedikit batu lodak dan batu lumpur pada beberapa bahagian. Struktur sedimen seperti pelapisan silang banyak ditemui pada jujukan unit ini. Singkapan di Tanjung Lembung turut memperlihatkan fasies heterolitik jenis pelapisan flaser, pelapisan bergelombang dan pelapisan lentikular yang menggambarkan aktiviti ombak. Batuan unit ini turut mengalami metamorfisme di beberapa singkapan seperti di Kuah, akibat rejahan granit.

Usia dan sekitaran pengendapan Tiada rekod fosil yang direkodkan dan ditemui di dalam unit ini. Usia bagi unit ini dianggarkan lebih muda daripada lapisan fosil paling muda 
di dalam Ahli Selang (Sakmarian) dan lebih tua daripada usia lapisan paling bawah Formasi Chuping (Kungurian). Oleh itu, usia bagi unit ini dianggarkan berusia Artinskian. Unit Ahli Lembung ditafsirkan terbentuk di sekitaran yang bertenaga tinggi dengan sedimen bersaiz pasir diendapkan. Kewujudan fasies heterolitik di dalam unit ini menunjukkan terdapat pengaruh ombak di kawasan pasang surut ketika pengenapan berlaku. Oleh itu, unit ini boleh disimpulkan terendap di kawasan yang cetek iaitu dari zon pasang surut hingga ke zon muka pesisir.

\section{KESIMPULAN}

Keputusan analisis hubungan antara jujukan batuan bagi keseluruhan Formasi Singa dapat merumuskan bahawa Formasi Singa boleh dibahagikan kepada 4 ahli iaitu Ahli Kentut, Ahli Ular, Ahli Selang dan Ahli Lembung. Ahli Kentut merupakan ahli yang paling tua diikuti dengan Ahli Ular, Ahli Selang dan Ahli Lembung. Ahli Ular di dalam Formasi Singa dianggap sebagai satu unit kekanta di antara Ahli Kentut dengan Ahli Selang kerana taburan Ahli Ular hanya boleh diperhatikan di Zon E (Pulau Ular), semakin menipis ke baratdaya (Zon B) dan tidak ditemui di bahagian lain. Beberapa siri perubahan paras laut juga dapat diperhatikan sepanjang pengenapan batuan Formasi Singa dengan beberapa siri proses transgresi dan regresi dikenal pasti. Perubahan paras laut ini berlaku akibat daripada proses pencairan glasier serta pengenapan sedimen yang menyebabkan lembangan menjadi semakin cetek.

\section{PENGHARGAAN}

Terima kasih diucapkan kepada Universiti Kebangsaan Malaysia kerana menyediakan kemudahan prasarana terutamanya peralatan makmal di Pusat Penyelidikan Langkawi, Kampus Tuanku Abdul Halim Mu'adzam Shah, Langkawi dan juga makmal di Fakulti Sains dan Teknologi, kampus Bangi. Penyelidikan berkenaan Formasi Singa ini telah dibiayai oleh projek penyelidikan Arus Perdana (AP2014-007) dan FRGS/2/2014/STWN06/UKM/01/1.

\section{RUJUKAN}

Ahmad Jantan. 1973. Stratigraphy of the Singa Formation (Upper Paleozoic) in the Southwestern part of Langkawi Island Group, West Malaysia. Tesis Sarjana Sains. Universiti Malaya (tidak diterbitkan).

Gobbett, D.J. 1972. Geology of the Rebak Islands, Langkawi, West Malaysia. Geological Society of Malaysia Newsletter 37: 1-5.

Hamada, T. 1968. Ambocoeliids from Red Beds in the Malaysan Peninsula. Dlm. Geology and Palaeontology of Southeast Asia. 5, disunting oleh Kobayashi, T. \& Toriyama, R. Tokyo: The University of Tokyo Press. pp. 13-25.

Hamada, T. 1969. Late Palaeozoic brachiopods from red beds in the Malayan Peninsula. Dlm. Geology and Palaeontology of Southeast Asia 6, disunting oleh Kobayashi, T. \& Toriyama, R. Tokyo: The University of Tokyo Press. pp. 251-264.
Ibrahim Abdullah. 1997. Evolusi struktur Kepulauan Langkawi. Warisan Geologi Malaysia - Pemuliharaan untuk Ekopelancongan. Bangi: Institut Alam dan Pembangunan (LESTARI). pp. 119-134.

Jones, C.R. 1966. Peta Geologi Kepulauan Langkawi. Helaian 150. Skala 1 : 63,360. Kuala Lumpur: Jabatan Penyiasatan Kajibumi Malaysia.

Jones, C.R. 1981. Geology of Perlis, North Kedah and the Langkawi Islands. Geological Survey of Malaysia District Memoir 17.

Khoo, T.T. 1984. Evidence of poly metamorphism in the Rebak Islands, Langkawi, Kedah. Bulletin of the Geological Society of Malaysia 17: 265-281.

Kobayashi, T. \& Hamada, T. 1973. Cyrtosymbolids (Tribolita) from the Langgun Red Beds in Northwest Malaya, Malaysia. Geology and Palaeontology of Southeast Asia 12. Tokyo: The University of Tokyo Press. pp. 1-26.

Koopmans, B.N. 1965. Structural evidence for a Paleozoic orogeny in north-west Malaya. Geological Magazine 102(6): 501-520.

Leonova, T.B., Mohd. Shafeea Leman \& Shi, G.R. 1999. Discovery of an Early Permian (Late Sakmarian) ammonoid form Langkawi Island, Malaysia. Alcheringa 23: 277-281.

Mat Niza Abdul Rahman, Hamid Ariffin, Mohamad Hussein Jamaluddin \& Imsamut, S. 2014. Lithostratigraphic correlation of the Rebak/Khuan Klang Formation along the Malaysia-Thailand border area. Proceeding National Geoscience Conference 2014. pp. 199-201.

Mohamad Hanif Kamal Roslan, Che Aziz Ali \& Kamal Roslan Mohamed. 2016. Fasies dan sekitaran sedimen Formasi Singa di Langkawi, Malaysia. Sains Malaysiana 45(12): 1897-1904.

Mohamad Hanif Kamal Roslan, Che Aziz Ali, Kamal Roslan Mohamed \& Mohd. Shafeea Leman. 2017. Taburan fosil dan penilaian semula usia Formasi Singa di Langkawi, Kedah Darul Aman, Malaysia. Sains Malaysiana 46(12): 2359-2365.

Mohd Shafeea Leman. 2003. An Early Permian (Early Sakmarian) brachiopod fauna from the Sungai Itau Quarry and its relationship to other Early Permian brachiopod horizon in Langkawi, Malaysia. Bulletin of the Geological Society of Malaysia 46: 155-160.

Mohd Shafeea Leman. 1997a. Batuan Formasi Singa di Pulau Langkawi. Dlm. Warisan Geologi Malaysia - Pemuliharaan untuk Ekopelancongan, disunting oleh Ibrahim Komoo, Mohd Shafeea Leman, Kadderi Md Desa \& Ibrahim Abdullah. Bangi: Institut Alam dan Pembengunan (LESTARI). pp. 185-207.

Mohd Shafeea Leman. 1997b. The age and paleobiogeography of brachiopod fauna discovered in pebbly mudstone at Kilim, Langkawi. Bulletin of the Geological Society of Malaysia 40: 233-240.

Mohd Shafeea Leman. 1996. The occurrences of brachiopods from pebbly mudstone near Kilim, Langkawi: Their age, paleobiogeography and paleoclimatic implication. Warta Geologi 22(2): 100-102.

Sarkar, S.S. 1972. On the Posidonia from Rebak Islands Langkawi, West Malaysia. Geological Society of Malaysia Newsletter 37: 5-9.

Shi, G.R., Mohd. Shafeea Leman \& Tan, B.K. 1997. Early Permian brachiopods from the Singa Formation of Langkawi Island, northwestern Peninsular Malaysia: Biostratigraphical and biogeographical implications. The International Conference on Stratigraphy and Tectonic Evolution of Southeast Asia and the South Pacific. pp. 62-72 
Yancey, T.E. 1972. Devonian fossils from Pulau Rebak Besar, Langkawi Island, West Malaysia. Geological Society of Malaysia Newsletter 37: 10-12.

Mohamad Hanif Kamal Roslan, Che Aziz Ali \&

Kamal Roslan Mohamed*

Pusat Penyelidikan Langkawi

Institut Alam Sekitar dan Pembangunan (LESTARI)

Universiti Kebangsaan Malaysia

46300 UKM Bangi, Selangor Darul Ehsan

Malaysia
Che Aziz Ali \& Kamal Roslan Mohamed*

Pusat Pengajian Sains Sekitaran \& Sumber Alam

Fakulti Sains dan Teknologi

Universiti Kebangsaan Malaysia

46300 UKM Bangi, Selangor Darul Ehsan

Malaysia

*Pengarang untuk surat-menyurat; email: kamal@ukm.edu.my

Diserahkan: 27 Mac 2018

Diterima: 8 Jun 2018 